Columbia Law School

Scholarship Archive

2014

\title{
Fifteen Years of Supreme Court Criminal Procedure Work: Three Constitutional Brushes
}

Daniel C. Richman

Columbia Law School, drichm@law.columbia.edu

Follow this and additional works at: https://scholarship.law.columbia.edu/faculty_scholarship

Part of the Constitutional Law Commons, Criminal Law Commons, and the Criminal Procedure Commons

\section{Recommended Citation}

Daniel C. Richman, Fifteen Years of Supreme Court Criminal Procedure Work: Three Constitutional Brushes, NÉo ou RÉTRo CONSTITUtIONNALISMES? (R)ÉVOLUTIONS DES DÉMOCRATIES CONSTITUTIONNELLES (1989-2015), Olivier Cayla \& Jean Louis Halpérin, Eds., MARe \& MARTIn, 2019; Columbia Public LaW RESEARCH PAPER No. 14-425 (2014).

Available at: https://scholarship.law.columbia.edu/faculty_scholarship/1884

This Working Paper is brought to you for free and open access by the Faculty Publications at Scholarship Archive. It has been accepted for inclusion in Faculty Scholarship by an authorized administrator of Scholarship Archive. For more information, please contact scholarshiparchive@law.columbia.edu. 


\section{COLUMbia LaW SchOOL}

PUBLIC LAW \& LEGAL THEORY WORKING PAPER GROUP

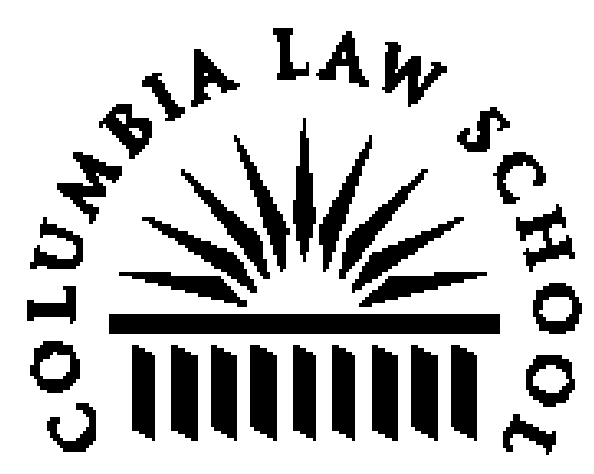

PAPER NUMBER 14-425

FIFTEEN YEARS OF SUPREME COURT CRIMINAL PROCEDURE WORK:

THREe Constitutional BRUSHES

DANIEL RICHMAN

OCTOBER 2, 2014 
Paris conference essay $10 / 2 / 14$

Fifteen Years of Supreme Court Criminal Procedure Work: Three Constitutional Brushes

\section{By Daniel Richman}

Perhaps my association of Paris with artists has provoked the metaphors in this conference essay. But I don't think so, for it's hard (for me at least) to teach recent US constitutional cases in the crime and security area without thinking in brush stoke terms. How else can one pull together a quarter-century of cases in which the US Supreme Court's constitutional interventions have taken the form, on one hand, of thin and clear doctrinal lines on miniature doctrinal canvases that have only passing connections to criminal justice realities, and on the other, of vague promises of judicial interest that leave most of the hard work of norm articulation to other institutions? It would be convenient to find a unifying theme across the Court's deployment of such diverse styles in some notion of judicial competence or capacity to effect change. But, as will be seen, the Court's articulated ambitions have regularly exceeded its achievements. Alternatively one can suggest that the Court has in each case picked a brush it thought appropriate, and sometimes misjudged its work's usefulness. But that is too tautological to be useful.

Lacking a grand explanatory theory, I will focus instead on identifying three different styles and invite readers to join me in figuring out the reasons for their use and their fitness for purpose. One elaborately articulates doctrine but, either by design or effect, occupies a small field. A second takes on a far larger regulatory subject but takes extreme care to limit the scope of its intervention. A third hints at sweeping structural ambitions reminiscent of the Warren Court's Criminal Procedure Revolution, but ends ups relying heavily on or collaborating with other regulatory authorities.

Readers undoubtedly can come up with more than three styles. But, in any event, the exercise highlights the limited nature of the Court's work during this period, as well as the limits of formalism in the area. It also quietly suggests the need for scholars to disaggregate broad references to "constitutionalism."

\section{Current Constitutional Ambitions and Past Constitutional History}

Listening to conversations about crime and domestic security issues in policy circles and the public square might easily lead one to believe that constitutional law - real or aspirational - is the most fit and available source of guidance. For better or worse and I think for worse -- rights conversations have a privileged status in debates about government programs, regardless of whether they merely implicate or actually violate established constitutional norms. Yet when it comes to the actual constitutional output of the Supreme Court, the world looks very different. Indeed, as I will show here, the Court's most conspicuous and sustained criminal rights projects have amounted to highly

\footnotetext{
- Paul J. Kellner Professor, Columbia Law School. Thanks to Bernard Harcourt for organizing the conference, to the French National Research Agency for funding it, to participants for very useful responses, and to Rebecca Brown, Michael Graetz, Jamal Greene, and David Sklansky for enormously helpful comments on previous drafts.
} 
developed but extraordinarily thin judicial interventions into messy and previously avoided aspects of adjudication process.

First, a baseline point: One must take care when comparing the Court's limited constitutional forays to the large-scale regulatory projects the Court pursued during the Criminal Procedure Revolution of yore. In the sprawling, largely county-based, American criminal justice system, no constitutional intervention will be truly transformative. Not only has the Supreme Court - and state constitutional courts - historically taken care not to radically outpace the political branches, but local experimentation and political dynamics will inevitably put some jurisdictions ahead of doctrinal change.

Consider the Warren Court's much heralded creation of the right to counsel for all indigent defendants in felony cases, ${ }^{1}$ and then the Burger Court's extension of that right to any misdemeanor prosecution that results in jail time. ${ }^{2}$ Where a state had not previously provided counsel, these were indeed dramatic and consequential decisions. In those states that already provided counsel, not so much. Still, although few would claim that Gideon's promise has been achieved, no one doubts its transformative effect, even where it has been limited to a constant war between constitutional doctrine and competing resource demands.

Or consider Miranda - which barred the use against a defendant of statements he made during a custodial interrogation unless he had been informed of his right to silence and to consult with an attorney -- another signature Warren Court constitutional decision. Here, too, an important institutional actor - in this case, the FBI - had anticipated the Court's move and shown its manageability. ${ }^{3}$ And police officers have come to live comfortably with Miranda, profiting from its clarity and sometimes circumventing its strictures. ${ }^{4}$ Yet we can still see the decision as a large-scale intervention into stationhouse practices, and it's still criticized for doing just that. ${ }^{5}$ Indeed, there are reasons why broad constitutional rulings should be the norm in the area. As Donald Dripps has noted, "the institutional context of criminal procedure doctrine - characterized by a high volume of cases, costly retrials as the dominant remedy, and legislative neglect" argues strongly for rule-like opinions that tell police and lower courts what the law is. ${ }^{6}$

It's hardly interesting that the Court's recent criminal procedure forays fall short of some imagined or real Warren Court baseline. Of course they don't, and no one

\footnotetext{
${ }^{1}$ Gideon v. Wainwright, 372 U.S 335 (1963).

2 Argersinger v. Hamlin, 407 U.S. 25 (1972).

${ }^{3}$ Miranda v. Arizona, 384 U.S. 486, 508 (1966) (noting that the FBI practice "can readily be emulated by state and local enforcement agencies"); Bernard Schwartz, Super Chief: Earl Warren and His Supreme Court, 589 (1983) (exploring role that FBI practice played during the Justices' deliberations in Miranda).

${ }^{4}$ See, e.g., Richard A. Leo, Miranda's Revenge: Police Interrogation as a Confidence Game, 30 L. \& Soc. Rev. 259 (1996); Charles D. Weisselberg, Saving Miranda, 84 Cornell L. Rev. 109, 154 (1998) (discussing questioning "outside Miranda").

${ }^{5}$ See Paul Cassell \& Richard Fowles, Handcuffing the Cops? A Thirty-Year Perspective on Miranda's Harmful Effects on Law Enforcement, 50 Stan. L. Rev. 1055, 1061 (1998).

${ }^{6}$ Donald Dripps, Constitutional Theory for Criminal Procedure: Dickerson, Miranda, and the Continuing Quest for Broad-But-Shallow, 43 Wm. \& Mary L. Rev. 1, 40 (2001).
} 
expects otherwise. Worth exploring, and my subject here, are the different ways in which the Court has fallen short. Leading scholars, most notably Cass Sunstein, ${ }^{7}$ have written about the Rehnquist Court's "minimalism," its case-by-case navigation of difficult terrain. But Court (both under Rehnquist and more recently) has not always navigated with care, and even when it does, there are different styles of navigation (or, to keep with my metaphor, of painting). In two conspicuous and sustained lines of cases, the Court's misty-eyed invocations of grand constitutional principles may lead one to miss the minimal effects of the elaborate doctrinal refinement on actual criminal processes. The result has the elaborate miniatures that I will discuss first. Then, I'll turn to a second style, where while potentially addressing a far larger range of cases - the ones that never go to trial -- the Court has proceeded gingerly, adding a few doctrinal lines but eschewing significant interference in the "bargaining" process. Finally, I'll consider what may be the Court's most consequential regulatory forays, which amount to hazy promises of greater judicial interest, in hopes that other institutions have or will add doctrinal nuance and clarity.

\section{Elaborate Miniatures}

Even as the Court has endeavored to deconstitutionalize certain aspects of police practice, ${ }^{8}$ it has embarked on two elaborate rights-articulation projects in the adjudication area -- the constitutionalization of sentencing procedure in the Apprendi/Blakely/Booker line of cases, and the reconfiguration of the Confrontation Clause right in Crawford and its progeny. Regularly returning to add (sometime inconsistent) lines, the Court sought to impose a new constitutional order on matters that had hitherto been left largely to jurisdictional (state or federal) choice.

\section{A. Apprendi/Blakely and the Constitutionalization of Sentencing Procedure}

Until the 1980s, constitutional regulation of sentencing procedures was extraordinarily minimalist by any measure. The Supreme Court's abstention (at least originally) purported to reflect a deep respect for the wide discretion that every jurisdiction had allowed sentencing judges and for the importance of highly individualized sentencing determinations. Thus in Williams $v$. New York, ${ }^{9}$ where a state judge had rejected a jury's recommendation of life imprisonment for a defendant convicted of first degree murder and had instead sentenced him to death on the basis of additional information not given to the jury but presented to the judge by the probation department, the Court found no violation of the defendant's due process rights.

\footnotetext{
${ }^{7}$ Cass R. Sunstein, Beyond Judicial Minimalism, 43 Tulsa L. Rev. 825 (2007); Cass R. Sunstein, One Case at a Time: Judicial Minimalism on the Supreme Court (2001); see also Neil S. Siegel, A Theory in Search of a Court, and Itself: Judicial Minimalism at the Supreme Court Bar, 103 Mich. L. Rev. 1951 (2005). ${ }^{8}$ See Herring v. United States, 555 U.S. 135 (2009) (restriction of exclusionary rule to exclude merely negligent violations, see fit it); Anthony O'Rourke, Structural Overdelegation in Criminal Procedure, $103 \mathrm{~J}$. Crim. L. \& Criminology 407, 408-08 (2013) (noting Court's recent tendency to delegate discretionary authority to enforcement officials).

${ }^{9} 337$ U.S. 241 (1949).
} 
Even as the Court (later) developed an elaborate capital punishment jurisprudence, ${ }^{10}$ its reliance on the Eighth Amendment's prohibition of "cruel and unusual punishments" to regulate the death penalty allowed it to leave the procedures governing all other criminal sanctions virtually unregulated. This abstention was - at least initially - done in the name of enlightened jurisprudence. The New York statute in Williams, Justice Black noted, reflected "a prevalent modern philosophy of penology that the punishment should fit the offenders, and not merely the crime." ${ }^{11}$ And that same modern approach counseled leaving sentencing judges unrestrained in the information they considered and the weight they gave it as they assessed a defendant's capacity for reformation and rehabilitation.

Over time, and to various degrees in various jurisdictions, sentencing reformers worried about undue disparities, arbitrariness, and racial discrimination combined with critics worried about undue judicial leniency to implement a variety of measures to restrain or eliminate judges' freedom to pick a sentence within very large statutory ranges. ${ }^{12}$ By the late $1980 \mathrm{~s}$, the clear trend across federal and state jurisdictions was to use some combination of guidelines and mandatory minimums to regulate sentencing and to reduce judicial sentencing discretion. Case facts - at least those presented to the judge by the prosecutor or defense counsel at sentencing, whether after trial or after a guilty plea - would now have much clearer sentencing consequences. A narcotics offense involving a particular amount of drugs would now require a sentence within some specified range; the use of a firearm in connection with the offense would lead to an additional amount of time, and so on. Sentencing would now be more driven by "law," through a regulatory regime that allowed both prosecution and defense to get appellate relief when a sentencing judge had failed to comply.

Even as the statutory consequences of sentencing-related factfinding became clearer (and often more punitive), the constitutional regime governing that process initially remained as it had been in the old discretionary days. In 1986, for instance, where a defendant complained about a Pennsylvania sentencing scheme that required a judge to impose a minimum sentence of five years' imprisonments if she found by a preponderance of evidence that the defendant had "visibly possessed a firearm" during the commission of his offense, the Supreme Court found no cause for concern. ${ }^{13}$ Visible possession, the Court found, was not an "element" of the offense - i.e. the sort of fact that had to be found by a jury (according to the Sixth Amendment) "beyond a reasonable doubt" (according to the due process clause). ${ }^{14}$ Rather, it was a mere "sentencing factor," and the state legislature had simply "dictated the precise weight" that judges should give one fact when setting the sentence within the broad statutory range. Indeed, given

\footnotetext{
${ }^{10}$ See, e.g., Carol Steiker \& Jordan M. Steiker. "Capital Punishment: A Century of Discontinuous Debate," 100 Journal of Criminal Law and Criminology 643 (2010); Carol Steiker \& Jordan Steiker. "Sober Second Thoughts: Reflections on Two Decades of Constitutional Regulation of Capital Punishment," 109 Harvard Law Review 355 (1995).

${ }^{11} 337$ U.S. at 247.

${ }^{12}$ See Kate Stith \& Jose Cabranes, Fear of Judging: Sentencing Guidelines in the Federal Courts (1998).

${ }^{13}$ McMillan v. Pennsylvania, 477 U.S. 79 (1986).

${ }^{14}$ See In re Winship, 397 U.S. 358 (1970) (Due Process requires proof beyond a reasonable doubt "of every fact necessary to constitute the crime with which [deft] is charged").
} 
growing concerns about the traditionally broad discretion allowed to judges, one could, (then) Justice Rehnquist noted, hardly quarrel with a legislative decision to reduce the scope of judicial discretion.

In 2000, however, the Court started to subject sentencing procedures to a more rigorous constitutional analysis. Confronted with a New Jersey regime that set a range of 5-10 years' imprisonment for possession of firearm for unlawful purpose but provided for an "extended term" of 10-20 years if a judge found, by a "preponderance" that the crime had been committed with the purpose to "intimidate" an individual or group because of "race, color, gender, handicap, religion, sexual orientation or ethnicity," the Court held that it violated the due process clause. A "factual determination authorizing an increase in the maximum prison sentence" had to, Justice Stevens (a dissenter in the 1986 Pennsylvania case) explained, be "made by a jury on the basis of proof beyond a reasonable doubt." 15

The Court took care to harmonize its new scrutiny of sentencing procedures that increased statutory maximums with its cases - like that from 1986 - allowing statutes that required the imposition of minimum sentences based on judicial factfinding. The process attending the imposition of far more consequential mandatory minimum sentences could thus be a lot more casual (no jury; no "beyond a reasonable doubt" standard) than the process that increased the possible maximum. ${ }^{16}$ Yet the Court continued to push forward, taking its biggest step in 2004, in Blakely v. Washington. ${ }^{17}$ There, the Court - this time with Justice Scalia writing the majority, joined by Stevens, among others - looked beyond the formal statutory maximums of the offenses the defendant had plead to and focused on the way the Washington guidelines regime had conditioned the imposition on an enhanced sentence (for kidnapping and domestic violence offenses) on a finding of "deliberate cruelty." Because the judge (and not a jury) had made just such finding (without any concession in that regard by the defendant), and had done so on the basis of a lower proof standard than that required at trial, his imposition of a sentence three years above the "standard range" allowed by the Washington guidelines, had violated defendant's Sixth Amendment right to trial by jury.

The change wrought by Blakely and a number of cases that followed in quick succession - involving the Federal Sentencing Guidelines, ${ }^{18}$ California's sentencing scheme, ${ }^{19}$ among other regimes - had its limits. A jurisdiction willing to give its sentencing judges broad discretion, without mandating that any specific sentencing consequence follow from the finding of pre-specified facts, was free to do so, without any need for jury findings on those facts a judge deemed significant or for higher proof burdens. But if a legislature opted for a regime in which specified facts had mandatory sentencing consequences (i.e. the prosecution could take an appeal from the judge who

\footnotetext{
${ }^{15}$ Apprendi v. New Jersey, 530 U.S. 466 (2000).

${ }^{16}$ See Harris v. United States, 536 U.S. 545 (2002) (reaffiming McMillian), overruled, Alleyne v. United States, 133 S. Ct. 2151 (2013).

${ }^{17}$ Blakely v. Washington, 542 U.S. 296 (2004).

${ }^{18}$ See United States v. Booker, 543 U.S. 220 (2005).

${ }^{19}$ Cunningham v. California, 549 U.S. 270 (2007)
} 
found the facts but refused to increase a sentence on that basis), those facts would have to be either found by a jury or admitted by the defendant as part of a guilty plea. The jury would thus, Scalia explained in Blakely, serve as a "circuit breaker" - the entity that would ensure that government doesn't misuse the criminal justice system to overpunish a defendant. In an era when legislatures were prone to curtail broad judicial sentencing discretion, the Court's new Sixth Amendment jurisprudence seemed to herald a sentencing revolution - to the chagrin of Justice Breyer, a key drafter of the Federal Sentencing Guidelines. ${ }^{20}$

The formalist mechanism set in motion in 2000 ground on through 2013, when the Court, in Alleyne v. United States, overruled prior precedent and finally held that the facts triggering mandatory minimums would also have to be found by a jury or admitted by the defendant at his plea. ${ }^{21}$ Writing for a majority that did not include Justice Scalia, Justice Thomas explained that "[d]efining facts that increase a mandatory statutory minimum to be part of the substantive offense," requiring that they be found by a jury, "preserves the historic role of the jury as an intermediary between the State and criminal defendants." 22

There may be a few more occasions for the Court's intervention as the ramifications of the 2013 decision get sorted out. ${ }^{23}$ Yet the fractured nature of the Alleyne Court suggests that this line of cases has run its course. So does the Court's readiness, in Oregon v. Ice (2009), ${ }^{24}$ to let judges, not juries, decide the facts on which turn perhaps the most consequential issue in a sentencing - whether the sentences imposed on a defendant convicted of multiple offenses run concurrently or consecutively. Writing for the Court - against a bitter dissent by Justice Scalia - Justice Ginsberg reasoned that this sort of fact finding was just the sort of thing judges had always done, and she dismissed the argument that a jury had to decide such a consequential matter as unduly formalistic. She explained:

All agree that a scheme making consecutive sentences the rule, and concurrent sentences the exception, encounters no Sixth Amendment shoal. To hem in States by holding that they may not equally choose to make concurrent sentences the rule, and consecutive sentences the exception, would make scant sense. Neither Apprendi nor our Sixth Amendment traditions compel straitjacketing the States in that manner. ${ }^{25}$

With a majority of the Court joining Justice Ginsburg to defend state sentencing experimentation, it is doubtful that this 15 -year-old constitutional intervention will extend much further.

\footnotetext{
${ }^{20}$ Blakely v. Washington, 296, 328 (2004) (Breyer, J. dissenting)

${ }^{21}$ Alleyne v. United States, 133 S. Ct. 2151 (2013).

${ }^{22}$ Id. at 2161.

${ }^{23}$ See Nancy J. King \& Bryann E. Applebaum, Alleyne on the Ground: Factfinding that Limits Eligibility for Probation or Parole Release, 26 Fed. Sent'g Rptr. 287 (2014); see also United States v. Wilkes, 744 F.3d 1101 ( $9^{\text {th }}$ Cir. 2014) (holding that Apprendi does not apply to criminal forfeiture).

${ }^{24}$ Oregon v. Ice, 555 U.S. 160 (2009)

${ }^{25}$ Id. at 171.
} 
So what was accomplished? As Frank Bowman - a leading American sentencing procedure scholar -- has noted:

[A] line of cases supposedly rooted in the Sixth Amendment's Jury Trial Clause might be deemed a success if it had achieved Justice Scalia's stated objective of reasserting the centrality of the jury to determination of facts essential to the determination of criminal punishments. But it has done nothing of the kind.

So far as can be determined, the advent of the Blakely-Booker sentencing era has neither increased the number of criminal jury trials nor materially expanded the number of sentence-affecting facts decided by juries in those trials that do occur. ${ }^{26}$

The irony of the Court's celebration of juries and its deployment of them to regulate sentencing is that this a regime with very few trials. Jurisdictions vary in the degree to which they are dominated by guilty plea dispositions. (The term "plea bargaining" is generally used, but in a country as punitive as the United States, these are rarely "bargains."). The general rule, however, is that more than $90 \%$ of all criminal convictions arise out of guilty pleas, not trials. ${ }^{27}$

If Blakely-Booker did not increase jury trials, perhaps it slightly increased a defendant's bargaining position with prosecutors. If the only way a particular sentencing enhancement could be imposed -- absent a jury (or bench) trial -- could be upon a defendant's admission to the facts supporting that enhancement, the defendant might exchange that admission for some sentencing concession from the prosecution, i.e. dispensing with a yet higher enhancement, or forgoing additional charges. Still, even if the new jury rights had this effect - and it far from clear that they did -- their marginal contribution to defendant bargaining power renders the Court's grand rhetoric about the jury's role superfluous. And it makes the Court's intervention into the process by which legislatures regulate the sentencing discretion exercised by trial judges a lot harder to justify.

So what did the Court think it was accomplishing? Mind reading is hard, but it is entirely possible that this entire constitutional project was triggered by the Court's outsized interest in federal sentencing. (Outsized because fewer than 5\% of U.S. felony prosecutions occur in federal courts. ${ }^{28}$ ) Even though Blakely involved Washington State sentencing, the Federal Guidelines - the subject of sustained criticism by lower court federal judges and the vehicle for increased congressional intervention in federal

\footnotetext{
${ }^{26}$ Frank O. Bowman, III, Debacle: How the Supreme Court Has Mangled American Sentencing Law and How It Might Yet Be Mended, 77 U. Chi. L. Rev. 367, 461 (2010).

${ }^{27}$ In Missouri v. Frye, 132 S. Ct. 1399, 1407 (2012), the Court drew on Justice Department statistics to report that "[n]inety-seven percent of federal convictions and ninety-four percent of state convictions are the result of guilty pleas."

${ }^{28}$ See Daniel Richman, Kate Stith \& William J. Stuntz, Defining Federal Crimes 2 (2014) (giving comparative statistics).
} 
sentences - were front and center. ${ }^{29}$ The Court's discovery of the Sixth Amendment's relevance to sentencing may primarily have been intended as both a rebuke to Congress and a magical solution to the legislative log-jam preventing sentencing reform. ${ }^{30}$ In this account, the impact on state systems may just be collateral damage from a clash between the federal political branches - with Congress and the Executive in close alliance - and the judicial branch.

It is too early to assess the impact this Sixth Amendment foray has had on sentencing across US jurisdictions. Debate continues even as to whether it has much of an effect within the federal system. But if the Court's intervention is taken on its own, jury-focused terms, its intensity and duration have been radically out of proportion to its systemic effects.

\section{B. Crawford and the New Confrontation Clause}

Even as 2004 saw the Court, in Blakely, extend constitutional regulation of sentencing procedure beyond formal statutory maximums to effective guideline maximums, so too did it see another dramatic Sixth Amendment intervention - this one affecting the prosecution's evidence in criminal trials. Here too, Justice Scalia's originalist conception of that provision anchored the Court's work. ${ }^{31}$ And here too have criminal justice realities and variable support from his colleagues started to make it into another constitutional miniature.

Before 2004, Confrontation Clause doctrine was powered by an easy pragmatism. Criminal defendants had a right to confront - to see and cross-examine - the witnesses called by the prosecution to prove its case against them. The Court recognized, however, that the ability to confront an in-court witness was of limited value if she simply relayed the statements of an out-of-court declarant, with the prosecution relying on the truth of those statements (i.e. introducing hearsay). It therefore read the Clause to reflect a "preference" for face-to-face confrontation at trial whenever an absent declarant's statements were offered for their truth. ${ }^{32}$ If the declarant was unavailable or if her statement had some independent evidentiary value, ${ }^{33}$ however, the hearsay could be introduced without violating the Clause so long as it either fell within a "firmly rooted hearsay exception" or bore "particularized guarantees of trustworthiness.",34 After all, both the Clause and hearsay doctrine, with its manifold exceptions, were designed to protect the same goal of reliability. And luckily for prosecutors, law students, and fans of simplistic doctrinal analysis, it turned out that pretty much all of the hearsay exceptions

\footnotetext{
${ }^{29}$ See Kate Stith, The Arc of the Pendulum: Judges, Prosecutors, and the Exercise of Discretion, 117 Yale L.J. 1420 (2008).

${ }^{30}$ See Daniel Richman, Federal Sentencing in 2007: The Supreme Court Holds - The Center Doesn't, 117

Yale L.J. 1374 (2008).

${ }^{31}$ See Stephanos Bibas, Originalism and Formalism in Criminal Procedure: The Triumph of Justice Scalia, the Unlikely Friend of Criminal Defendants, 94 Geo. L.J 183 (2005).

${ }^{32}$ Ohio v. Roberts, 448 U.S. 56, 63-64 (1980).

${ }^{33}$ See United States v. Inadi, 475 U.S. 387 (1986).

${ }^{34}$ Crawford v. Washington, 448 U.S. at 66.
} 
under federal and state law were "firmly rooted," and that state and federal lower court scrutiny of reliability was often lackadaisical. ${ }^{35}$

In 2004, Crawford completely changed this constitutional landscape. The Confrontation Clause, Justice Scalia now explained, had been designed to prevent incourt use of ex parte out-of-court witness examinations (of the sort conducted by Sixteenth Century magistrates in England). "An accuser who makes a formal statement to government officers bears testimony in a sense that a person who makes a casual remark to an acquaintance does not." To the extent a statement was obtained under analogous circumstances, it could not be offered for its truth in the absence of the declarant unless he was unavailable and had previous been cross-examined or when the framers had required otherwise. "Leaving the regulation of out-of-court statements to the law of evidence," Scalia noted "would render the Confrontation Clause powerless to prevent even the most flagrant inquisitorial practices."

Scalia's approach shifted the doctrinal focus away from the reliability of the outof-court statements: "To be sure, the Clause's ultimate goal is to ensure reliability of evidence, but it is a procedural rather than a substantive guarantee. It commands, not that evidence be reliable, but that reliability be assessed in a particular manner: by testing in the crucible of cross-examination." 37 This move made Confrontation Clause protection far more robust, to the extent the Clause applied. Statements deemed "testimonial" could no longer be introduced just because a judge had deemed them "reliable." But the negative implication of Crawford was that the Confrontation Clause had nothing to say about the introduction of non-testimonial statements. Prior doctrine purported to put all prosecutorial uses of out-of-court statements for their truth under constitutional scrutiny for "reliability" whenever the declarant did not testify at trial. Now, as a 2006 decision soon made clear, ${ }^{38}$ only "testimonial" statements would be the subject of a Confrontation Clause inquiry, and non-testimonial statements (no matter how dubious their reliability) would be beyond the clause's purview. Thus, a nice framed canvas, leaving out most hearsay statements.

Yet what present-day circumstances amounted to the ex parte examinations conducted by English Justices of the Peace under a statute from Queen Mary's reign? In its embrace of originalism as a constraint on judicial discretion, the Crawford Court offered some easy examples - grand jury testimony, guilty plea allocutions, and formal police interrogations - but, in this first pass at the new canvas, left lower court scant guidance for sorting through the various statements that unavailable witnesses had made to the police or other official actors in less formal settings. In time, the Court added new brush strokes, and in 2006, with Justice Scalia writing again, it held that statements in response to questioning by police officers, emergency operators or other law enforcement personnel are "testimonial" only when "circumstances objectively indicate . . . that the

\footnotetext{
${ }^{35}$ See Bibas, supra note _ , at 189-90; David Alan Sklansky, Hearsay’s Last Hurrah, 2009 Sup. Ct. Rev. 1, 39-40.

${ }^{36}$ Crawford, 448 U.S. at

${ }^{37}$ Crawford, 448 U.S. at -

${ }^{38}$ See Davis v. Washington, 547 U.S. 813, 824 (2006).
} 
primary purpose of the interrogation is to establish or prove past events potentially relevant to later criminal prosecution," rather than to respond to "an ongoing emergency.",39

To use Cass Sunstein's terms, ${ }^{40}$ these initial decisions were "deep," in the sense that they were robustly theorized, and were not particularly "narrow." To be sure, only statements deemed "testimonial" would be implicated. But the undemanding nature of prior doctrine - which generally found the Confrontation Clause satisfied in any case where local evidentiary rules allowed the admission of a statement under some sort of hearsay analysis ${ }^{41}$ - had made statements to law enforcement officials the main constitutional battleground. Now, the Court seemed to promise, the terms of those battles would be radically different. ${ }^{42}$

Critical members of the Court, however, soon recoiled from the ramifications of the project and prepared the basis for limiting it. In 2008, Giles v. California ${ }^{43}$ presented a sadly recurring scenario: a domestic violence murder prosecution in which the victim had previously told the police of prior instances of domestic violence by the defendant. Contestably assuming that the victim's statements were "testimonial," rejected the state's argument that, by causing the victim's unavailability (by murdering her), defendant had forfeited his constitutional right to confront her at trial with respect to those prior statements. Under common law both before the Founding and after, Scalia asserted, the defendant must be found to have specifically intended to prevent a declarant from testifying before he can be deemed to have forfeited his right to confront her. ${ }^{45}$

With the same trust in ordinary government processes and antipathy to formalism that pit him against Scalia in sentencing cases, Justice Breyer contested Scalia's reasoning here and asked:

What important constitutional interest is served [] where a prior testimonial statement of a victim of abuse is at issue, by a constitutional rule that lets that evidence in if the defendant killed a victim purposely to stop her from testifying, but keeps it out if the defendant killed her knowing she could no longer testify while acting out of anger or revenge ${ }^{46}$

\footnotetext{
${ }^{39}$ Id. at 822.

${ }^{40}$ See Sunstein, supra note _ ; see Neil S. Siegel, supra note__ (using Blakely and Crawford as examples of non-minimalist decisions).

${ }^{41}$ See Robert P. Mosteller, Giles v. California: Avoiding Serious Damage to Crawford's Limited Revolution, 13 Lewis \& Clark L. Rev. 675, 679 (2009) (characterizing the protection provided by Ohio $v$. Roberts as "a mile wide and an inch deep").

${ }^{42}$ See Tom Lininger, Prosecuting Batterers After Crawford, 91 Va. L. Rev. 747, 749 (2005) (noting that "within days - even hours - of the Crawford decision, prosecutors were dismissing or losing hundreds of domestic violence cases that would have presented little difficulty in the past").

${ }^{43}$ Giles v. California, 554 U.S. 353 (2008).

${ }^{44}$ Id. at 377 (Alito, J., concurring) (questioning whether statement were "testimonial").

45554 U.S. at 367.

${ }^{46} 554$ U.S at 380 (Breyer, J., dissenting) (joined by Stevens and Kennedy).
} 
And two members of Scalia's five-vote majority explained how, in the future, domestic violence prosecutors could circumvent his ostensibly demanding analysis by using an abusive relationship as a basis for presuming a specific intent to prevent the victim from testifying. This appears to be a path that prosecutors have since taken. ${ }^{47}$

The breadth and depth of Scalia's Crawford project also brought it into conflict with the realities of forensic evidence. First came a relatively easy (at least in hindsight) case. In Melendez-Diaz v. Massachusetts, ${ }^{48}$ the Court (with Scalia writing for the majority) held that the out-of-court statements of forensic scientists were to be treated like those of any other witness, and that the Confrontation Clause had been violated when the state had allowed a laboratory analyst's sworn certification about seized drugs to substitute for the actual testimony of government chemists. ${ }^{49}$ Two years later, the Court, by 5 to 4 , held that the state could not prove up the contents of blood alcohol report by calling an analyst who had neither conducted the tests nor prepared the report. ${ }^{50}$ Yet one of the five (Justice Sotomayor, who had replaced Souter), suggested that the analysis might be different had the absent analyst's testimonial certification merely been relied on by the testifying expert as a basis for his own independent conclusion. ${ }^{51}$ This is quite a loophole, and one that, in 2012. Justice Alito and three colleagues were willing to drive a truck through in Williams $v$. Illinois - a case where a police lab analyst's testimony relied explicitly and heavily on DNA reports submitted by a contract lab. ${ }^{52}$ This approach drew a sharp dissent from Justice Kagan - joined by Scalia, among others - who labeled "the idea that such 'basis evidence' comes in not for its truth, but only to help the factfinder evaluate an expert's opinion" "nonsense" and "sheer fiction." 53 That is where things now stand: with the court divided 4 to 4 , with the missing vote being Justice Thomas -- who shares Kagan's view of the inadequacy of Alito's opinion, but whose extremely narrow definition of "testimonial" does not include lab reports like the ones in Williams that are "not the product of any sort of formalized dialogue resembling custodial interrogation."

The fractured state of the Williams Court seems (as of 2014) to have put the Crawford project on hiatus, at least with respect to forensic evidence. Presumably because it doesn't feel capable of adding value (until a mind or the composition of the Court changes), the Court has retreated from this line of business, leaving the lower courts to grapple with important and recurring issues involving, among other things, reports of autopsies conduct by now-unavailable pathologists.

\footnotetext{
${ }^{47}$ See Michael Vargas, Note, Prosecuting Domestic Violence After Giles: Why a Categorical Approach to the Forfeiture Doctrine Threatens Female Autonomy, 20 Duke J. Gender L. \& Policy 137, 174 (2012).

48557 U.S. 305 (2009).

49 Jennifer Mnookin \& David Kaye, Confronting Science: Expert Evidence and the Confrontation Clause, 2013 Sup. Ct. Rev. 99, _ (2013).

${ }^{50}$ Bullcoming v. New Mexico, 131 S. Ct. 2705 (2011).

${ }^{51}$ Id. at 2721-23 (Sotomayor, J., concurring).

52132 S. Ct. 2221 (2012).

${ }^{53}$ Id. at 2269 (Kagan, J., dissenting).

${ }^{54}$ Id. at 2260 (Thomas, J., concurring).
} 
Meanwhile, even the core meaning of Crawford has been eroded. By 2011, in Michigan v. Bryant, ${ }^{55}$ the Court showed fatigue with or even regrets about the whole project. Here, police officers, responding to a call about a shooting, found a gunshot victim. Upon being asked what had happened, the man described the shooter and thereafter died. Upholding the introduction of this statement at the subsequent trial of person identified, the Court, in an opinion by Justice Sotomayor, held that a decision about whether the statements were "testimonial" required consideration not just of the declarant's motives but those of his interrogators, who faced the public safety emergency of a loose shooter. "Because the circumstances of the encounter as well as the statements and actions of [the victim] and the police objectively indicate that the "primary purpose of the interrogation' was 'to enable police assistance to meet an ongoing emergency,", the statements were not testimonial. ${ }^{56}$

The significance of Michigan v. Bryant doesn't lie in its result. After all, a "dying declaration" analysis - had it been properly developed in the lower courts - might have avoided any inquiry into the statement's "testimonial" nature. Nor does it lie simply lie in the Court's move to a "combined inquiry" into motivation rather than a declarantcentered one - even though that move itself provoked Justice Scalia's ire. Rather what led him - writing only for himself, as one of only dissenters -- to declare that "today's opinion distorts our Confrontation Clause jurisprudence and leaves it in a shambles" was Sotomayor's readiness to collapse the new Crawford inquiry into the old malleable hearsay "reliability" inquiry and to barely conceal the change.

It is too soon to tell if Bryant presages a return to status quo ante Crawford, though many have understandably read it just that way. ${ }^{58}$ But I suspect that it does mark the end of the Court's interest in regulating the introduction at trial of arguably "testimonial" statements by non-testifying witnesses. Defendants will henceforth enjoy Confrontation Clause protection when statements were made in set-piece police interrogations, grand jury appearances, and analogous situations. Beyond these easy cases, I expect lower courts to make fact-sensitive calls and the Supreme Court to remain on the sidelines.

Assuming this prediction is correct, one should not dismiss the Court's sustained intervention as having achieved nothing. Although Scalia's opinion in Crawford was grounded in originalism, it was, I suspect, the formalism of his analysis that got him a majority, for it seemed to promise an end to what Scalia fairly called a "malleable standard" that had often failed to protect defendants against "paradigmatic confrontation violations." While Bryant substantially pruned the paradigm that Scalia had in mind and will spark a lot of "reliability" inquiries of the sort Scalia worried about, violations of Crawford's core protection - against evidence obtained from what amount to ex parte

\footnotetext{
${ }^{55} 131$ S. Ct. 1143,1150 (2011).

${ }^{56}$ Id. at 1150 (quoting Davis, 547 U.S. at 822).

${ }^{57} 131 \mathrm{~S}$ Ct. at 1168 (Scalia, J., dissenting).

${ }^{58}$ See Brooks Holland, Crawford and Beyond: How Far Have We Traveled from Roberts After All?, 2 Bklyn. J. L. \& Policy, 517, 518 (2012) (“"Bryant thus put the brakes on the Crawford train, and maybe even started its return to the Roberts station.").

${ }^{59}$ Crawford, 541 U.S. at 60.
} 
examinations of non-testifying witnesses - will remain a lot less likely in those courtrooms familiar with the Supreme Court's work. Perhaps Justice Thomas, whose highly formal definition of "testimonial" left him writing many opinions for himself, had the right idea all along (at least if "right" is judged in predictive terms).

At the same time, the thinness of even the right broadly announced in Crawford ought not be forgotten. Once a statement is deemed to be "testimonial," the prosecution generally cannot offer it without calling the declarant to the stand - assuming the defendant did not forfeit his confrontation right or have a prior opportunity to confront. Constitutionally mandated "confrontation," however, does not require that, once testifying, the declarant have any memory of having made the prior declaration, or even of the underlying facts. At least such appears to be the current state of the law, even where (in a sadly recurring scenario) a child sex abuse victim -- having been interviewed before trial for prosecution purposes - takes the stand but remembers little or nothing about either the interview or the sex abuse recounted in it. ${ }^{60}$ Nor does the current constitutional understanding of "confrontation" give defense a general right to disclosure from the prosecution of materials that would promote effective confrontation.

\section{Conclusion}

The Apprendi and Crawford sagas certainly show what the Court's sustained attention to constitutional criminal procedure projects can look like. Do they also show something about the limits - perceived or inherent - of such projects? When one starts with a multi-member judicial bloc with heterogeneous preferences and adds changes in Court composition, answering such basic questions is hard indeed. Had the Court been more united in its support for each project, perhaps its interventions might well have been more sustained in time and more conceptually robust. Yet each formalistic project had a self-limiting quality - as if the Court felt freest to lay down clear lines only when it painted on small canvases.

\section{Putting Up Posters in the Marketplace}

The stories of Crawford and Apprendi might lead one to cast the Court as an arcane bystander of the regular criminal process. How else can one think of an institution that deployed originalist doctrines grounded in an anachronistic celebration of trials and then quietly retreated in the face of the implementation challenges endemic in a sprawling criminal justice system where convictions usually come from guilty pleas, and where police officers at or near crime scenes are nothing like Marian magistrates. But the fine (albeit wavering) hand the Court used in those cases is not its only style. Indeed, in the long term, the Court's more episodic constitutional forays into the relatively

\footnotetext{
${ }^{60}$ See State v. Cameron M., 307 Conn. 504, 520 n. 18 (2012) (collecting state cases); People v. Eagle, 2014 WL 667654, Cal. App. 4 Dist. (2014). For an outlier case finding, in wake of Crawford, that confrontation requires more than more the physical presence of a willing witness, see Goforth v. State, 70 So.3d 174 (Miss. 2011). The last word from the Supreme Court on the issue came in United States v. Owens, 484 U.S. 554,559 (1988) (finding confrontation right "not denied when a witness testifies as to his current belief but is unable to recollect the reason for that belief.").
} 
unregulated thicket of plea bargaining and defense advocacy may - even though they amount to a few posters in the marketplace (or few black lines against a grey background, if the brushstroke metaphor is working for you)--- be of more lasting significance. And they seem both far removed from formalism and ungrounded in originalism.

First, a quick overview of the constitutional underpinnings of the plea bargaining process that constitutes the real adjudication process for most criminal defendants. In the 1970s, the Court laid down the basic doctrinal pieces. A defendant's entry of guilty plea is not inappropriately coerced merely because the prosecution has obtained it either by threatening to bring more severe charges or offering to reduce the pending charges. ${ }^{61}$ And the prosecution must keep the promises made to induce that guilty plea. ${ }^{62}$ The regime has come to have much in common with private contract law. ${ }^{63}$ Defendants have trial rights they can negotiate away. Prosecutors have the bargaining leverage created by the available evidence and the (increasingly broad) array of charging possibilities established by the legislature, with super-strong norms of prosecutorial discretion leaving their choices among punitive options unregulated by courts. And notwithstanding cogent critiques of rules that tolerate the effective imposition of a penalty on those defendants with the temerity to stand trial, a robust system of negotiated dispositions has flourished in every jurisdiction.

Even the most pragmatic effort to justify this model of defendant "autonomy" would require some guarantee that defendants - particularly the $80 \%$ or so who could not afford counsel and were provided with lawyers by the state ${ }^{64}$-- receive adequate legal representation. But the literature reporting systemic inadequacies on this score has been piling up for decades. ${ }^{65}$ Even so, and in the absence of widespread political commitment to ensuring defender adequacy, the Supreme Court's contribution has been limited. In 1984, in Strickland v. Washington, ${ }^{66}$ it established what soon became the general constitutional framework for assessing whether a convicted defendant's Sixth Amendment right to counsel has been violated. To prevail, a defendant needs to show not only that "counsel's representation fell below an objective standard of reasonableness," but that there was "a reasonable probability that, but for counsel's unprofessional errors, the result of the proceeding would have been different." ${ }^{67}$ Thereafter, in 1985, the Court gingerly applied this two-prong analysis to one aspect of the plea process, and held that a defendant who had pled guilty on the advice of counsel could get his conviction overturned for "ineffective assistance of counsel" if he could show that counsel's

\footnotetext{
${ }^{61}$ See Brady v. United States, 397 U.S. 742 (1970) (voluntariness standard); Bordenkircher v. Hayes, 434 U.S. 357 (1978); William J. Stuntz, Bordenkircher v. Hayes: Plea Bargaining and the Decline of the Rule of Law, in CRIMINAL PROCEDURE STORIES 351 (Carol S. Steiker ed., 2006) (criticizing Bordenkircher).

${ }^{62}$ Santobello v. New York, 404 U.S. 257 (1971).

${ }^{63}$ See Robert E. Scott \& William J. Stuntz, Plea Bargaining As Contract, 101 YALE L.J. 1909 (1992).

${ }^{64}$ See Caroline Wolf Harlow, Bureau of Justice Statistics, Defense Counsel in Criminal Cases (2000) (approximately $66 \%$ of felony Federal defendants and $82 \%$ of felony defendants in large State courts represented by public defenders or assigned counsel).

${ }^{65}$ See Mary Sue Backus \& Paul Marcus, The Right to Counsel in Criminal Cases, A National Crisis, 57

HASTINGS L.J. 1031 (2006);

${ }^{66} 466$ U.S. 668 (1984).

${ }^{67}$ Id. at $688,694$.
} 
performance was objectively unreasonable and that there was "a reasonable probability that, but for counsel's errors, he would not have pleaded guilty and would have insisted on going to trial.",68

From time to time in the succeeding decades, the Court gave somewhat more content to the Strickland framework, generally in the context of death penalty cases. ${ }^{69}$ But defense successes were scarce, mostly because courts - particularly outside of the capital cases, where the "result" that might have been different was the death sentence, not just the guilt determination -- found it easy to find that, even with better lawyering, defendants would still have been convicted. ${ }^{70}$

Two stable aspects of Strickland doctrine precluded a host of criminal defendants from even articulating ineffective assistance claims: the assumption that only legal advice about the criminal case itself, not "collateral consequences" of conviction, was of constitutional interest, and the assumption that a defendant who "enjoyed" his constitutional right to trial and was adequately represented at trial had nothing to complain about. Between 2010 and 2012, the Court relaxed, indeed dismantled, both assumptions in decisions that strained to balance a new recognition of criminal justice realities with a strong and explicit desire - of the sort not seen in Blakley and Crawfordto limit the impact of its work.

In 2010, in Padilla v. Kentucky, ${ }^{71}$ the Court held that a defense attorney who fails to advise a noncitizen client that a guilty plea will nearly certainly lead to deportation has failed to meet the constitutional standard of objective reasonableness. Because of deportation's "close connection to the criminal process" made it "uniquely difficult to classify as either a direct or a collateral consequence," Justice Stevens (writing for the Court) found the "collateral versus direct distinction" "ill-suited to evaluating a Strickland claim concerning the specific risk of deportation," and held that "advice regarding deportation is not categorically removed from the ambit of the Sixth Amendment right to counsel." 72 Justice Alito (joined by Chief Justice Roberts) concurred, but would have limiting the holding to cases where defense counsel gave legally incorrect advice. ${ }^{73}$ And Justice Scalia (joined by Justice Thomas) dissented, finding "no basis in text or in principle to extend the constitutionally required advice regarding guilty pleas beyond those matters germane to the criminal prosecution at hand - to wit, the sentence that the plea will produce, the higher sentence that conviction after trial might entail, and the chances of such a conviction.",74

\footnotetext{
${ }^{68}$ Hill v. Lockhart, 474 U.S. 52 (1985).

${ }^{69}$ See, e.g., Stephen B. Bright, Essay, Counsel for the Poor: The Death Sentence Not for the Worst Crime but for the Worst Lawyer, 103 Yale L.J. 1835 (1994).

${ }^{70}$ See Steven Zeidman, Padilla v. Kentucky: Sound and Fury, or Transformational Impact, 39 Fordham

Urb. L. J. 203, 212 \& n.35 (citing sources) (2011).

71559 U.S. 356 (2010).

${ }^{72}$ Id. at 366.

${ }^{73}$ Id. at 375 (Alito, J., dissenting).

${ }^{74}$ Id. at 388 (Scalia, J., dissenting).
} 
Padilla's effect should not be overstated. One scholar hailed it as "the Court's first case to treat plea bargaining as a subject worthy of constitutional regulation in its own right and on its own terms." ${ }^{.75}$ Others have been less effusive, noting that the decision does not change bargaining dynamics that make deportation unavoidable and that its impact may be reduced to a new line on a harried defender's check list. ${ }^{76}$ Save for a decision refusing to apply Padilla retroactively -- because it had so clearly "broke new ground" and announced a "new rule"77 -- the Court has stopped developing this line of doctrine, leaving lower courts to mostly (but not entirely) hold the line on efforts by defendants to apply the case to other consequences - like the obligation to register as a sex offender. ${ }^{78}$ Should Padilla be seen as an incremental move in a larger project to regulate what really matters in plea bargaining market place? It is far too soon to tell, but the important point, for our purposes, is that - in contrast to Crawford and Apprendi/Blakely -- further regulation is not a necessary implication of the decision. Moreover, the Court's regulatory focus on defense advocacy, rather than judicial advice or prosecutorial power highlights its restraint.

Perhaps a more consequential regulatory move - although one still focused on defense counsel performance -- came in a pair of 2012 cases, Lafler v. Cooper ${ }^{79}$ and Missouri v. Frye. ${ }^{80}$ These started, albeit very gingerly, to address the plight of the largest group of defendants overlooked by Strickland: those who never intended to go to trial but who would have received far better deals had their lawyers been any good. These decisions explicitly acknowledged "the reality that criminal justice today is for the most part a system of pleas, not a system of trials." ${ }^{\prime 1}$ The alleged inadequacy of the lawyer in Frye was straightforward: he had failed to tell his client about a plea offer from the prosecution that, thereafter, had expired, leaving him to face, and plead to, a more severe charge. The twist in Lafler was that the defendant ill-served in plea negotiations - here the lawyer had told the client about the favorable plea offer but incompetently advised him not to take it - had been convicted (with a higher sentence) after "a full and fair" jury trial. $^{82}$

Writing for the Court in both cases, Justice Kennedy moved in to "define the duty and responsibility of defense counsel in the plea bargain process, ${ }^{, 83}$ or, as Justice Scalia scornfully put it, "open up a whole new boutique of constitutional jurisprudence ('pleabargaining law')." ${ }^{, 4}$ In Frye, with little issue about the deficiency of counsel's

\footnotetext{
${ }^{75}$ Stephanos Bibas, Regulating the Plea-Bargaining Market: From Caveat Emptor to Consumer Protection, 99 Cal. L. Rev. 1117, 1120 (2011).

${ }^{76}$ See Darryl K. Brown, Why Padilla Doesn’t Matter (Much), 58 UCLA L. Rev. 1393 (2011); Zeidman, supra note

${ }^{77}$ Chaidez v. United States, 133 S. Ct. 1103 (2013).

${ }^{78}$ See State v. Trotter, 2014 UT 17 (Utah 2014) (holding that because the requirement to register as a sex offender is a "collateral consequence," defense counsel was not constitutionally required to inform the defendant about it).

${ }^{79} 132$ S Ct. 1376 (2012).

${ }^{80} 132$ S. Ct. 1399 (2012).

${ }^{81}$ Lafler, 132 S. Ct. at 1388.

${ }^{82}$ Id. at 1383.

${ }^{83}$ Frye, 132 S. Ct. at 1401.

${ }^{84}$ Lafler, at 1398 (Scalia J., dissenting).
} 
performance, the Court remanded to the state court for an inquiry into whether (1) the defendant would have accepted the lapsed plea; (2) the prosecution would have adhered to the agreement, and (3) the trial court would have "permitted the plea bargain to become final." 85 In Lafler, because defense counsel's inadequacy had been conceded and defendant had shown that "he and the trial court would have accepted the guilty plea" carrying a lighter sentence, the Court reasoned that the "correct remedy" was "to order the State to reoffer the plea agreement. Presuming respondent accepts the offer, the state trial court can then exercise its discretion in determining whether to vacate the convictions and resentence respondent pursuant to the plea agreement, to vacate only some of the convictions and resentence respondent accordingly, or to leave the convictions and sentence from trial undisturbed." 86

Quite the clash: what appears to be a bold extension of constitutional regulation into the plea bargaining process, coupled with an acknowledgement of prosecutorial control over charging concessions, and a remedy that appears to license an extraordinary degree of trial judge discretion. ${ }^{87}$ There is little reason to believe that many defendants will get the benefit of the slender doctrinal path to relief offered by Lafler and Frye. ${ }^{88}$ The defendant radically disadvantaged by his lawyer's failure to pursue a cooperation overture from the government is still almost certainly without recourse. ${ }^{89}$ Do these cases presage more substantial and sustained regulatory activity? Justice Scalia said they would, and noted that "it would be foolish to think that 'constitutional' rules governing counsel's behavior will not be followed by rules governing the prosecution's behavior in the plea-bargaining process that the Court today announces 'is the criminal justice system." "90 But dire predictions by dissenters should be discounted. Others have more calmly, and sanguinely, predicted that these cases will spark extrajudicial efforts to make the extension and nature of plea bargains more regular and law-like. ${ }^{91}$

Time will tell. Perhaps the world of Bordenkircher v. Hayes - the one that leaves prosecutors free to use inflated sentencing threats (which they often had a hand in legislating) to buy back ostensibly expansive constitutional rights from criminal defendants, and that tolerates the effective imposition of a penalty on defendants who chose to stand trial - may start to crumble. It certainly will be more transparent if prosecutors, to protect against later ineffective assistance claims, uniformly put plea

\footnotetext{
${ }^{85}$ Frye, 132 S. Ct. at 1401

${ }^{86}$ Lafler, 132 S. Ct. at 1391.

${ }^{87}$ See Wesley MacNeil Oliver, Toward a Common Law of Plea Bargaining, 102 Ky. L.J. 1 (2013-2014) (proposing that judges use their remedial powers to define appropriate uses of prosecutorial discretion). ${ }^{88}$ See Stephanos Bibas, Incompetent Plea Bargaining and Extrajudicial Reforms, 126 Harv. L. Rev. 150, 163 (2012) (“Given Strickland's enormous deference to attorneys' strategic decisions, the difficult of proving off-the-record bargaining behavior, and habeas courts' reluctance to reverse final convictions and grant substantial remedies, Lafler and Frye probably will free few inmates from prison.").

${ }^{89}$ See United States v. Ramirez, 751 F.3d 604 ( $8^{\text {th }}$ Cir. 2014) (finding that while the defense counsel did indeed fail to respond when the government expressed interested in defendant's cooperation, defendant failed to show "prejudice" because never showed reasonable probability that the government would actually have extended a formal plea offer and that defendant would have accepted it); see Daniel Richman, Cooperating Clients, (on critical role that defense counsel plays in decisions to cooperate)

${ }^{90}$ Lafter, at 1392 (Scalia, J., dissenting) (initial quotation marks omitted).

${ }^{91}$ See Bibas, Harv. L. Rev. at 2012
} 
offers and expiration dates on the record. And lower court judges have started to push hard at doctrines that tie their hands when the government responds to a defendant's decision to stand trial by adding new mandatory minimum charges. ${ }^{92}$ But so far the minimalist constitutional approach to guilty pleas that often seems to have more in common with a private law than a public law regime remains in place. And there is good reason to expect that the Court's slender and episodic interventions will be exceptions to the norm of a deconstitutionalized marketplace - a few clear lines on a largely unadorned canvas.

\section{Framing and Collaboration}

While the breadth, depth, and scope of the Court's Crawford and Apprendi/Blakely projects distinguish them from the relatively narrow interventions in Padilla and Frye/Lafler, all were constitutionally unilateral: doctrinal operations performed on, but not (except perhaps for the Lafler remedy) responsive to jurisdictional law and institutional choices. Whether looking to originalism or some more pragmatic sense of justice, the Court simply drew on its own constitutional resources for norm articulation.

But unilateral intervention is not the Court's only mode and may not even be its preferred mode, for real or potential constitutional norms are regularly articulated by other institutional actors - lower federal courts, state courts, Congress, and state legislatures. Indeed, the real "neo-constitutionalism" (to the extent one can identify it) may end up being a lot more collaborative than top down projects like those considered so far may suggest.

One gets a sense of the Court's attention to this external norm development even when the Court decides not to intervene. Consider Perry v. New Hampshire, ${ }^{93}$ where the defendant claimed that Due Process Clause offered him protection against an eyewitness identification that had made under unduly suggestive circumstances but that had not been orchestrated by the police. By 2012, when this case arose, the pitfalls of eyewitness identifications and the risks that juries were ill-equipped to assess the reliability of such witnesses had been well-documented, and had also been dramatized by a number of DNA exonerations. ${ }^{94}$ These reliability concerns were not restricted to cases in which the police had orchestrated the witness's contact with the suspect, but longstanding Supreme Court precedent made constitutional inquiry turn on just that factor. The Perry Court, however, refused to reconfigure its doctrine to require some "preliminary judicial assessment" of reliability in the absence of "improper law enforcement activity." Writing for the Court, Justice Ginsburg noted that "many state and federal courts" were already giving juries cautionary instructions about eyewitness testimony generally and that "[i]n appropriate

\footnotetext{
92 See, e.g. United States v. Kupa, 976 F. Supp.2d 417 (E.D.N.Y. 2013) (questioning government's policy of filing prior felony informations against defendants who go to trial); see also U.S. v. Young, 960

F.Supp.2d 881 (N.D.Iowa 2013) (questioning disparities in government's use of prior felony informations).

93132 S. Ct. 716, 721 (2012)

94 See Dan Simon, In Doubt (2012) (collecting literature);
} 
cases, some States also permit defendants to present expert testimony on the hazards of eyewitness identification evidence." 95

Notwithstanding the laissez faire result of the opinion, Justice Ginsburg was writing against a backdrop of not just experimentation with jury instructions and expert testimony but of elaborate intervention by some state courts, acting under their own state constitutions. ${ }^{96}$ Indeed, in 2011, the New Jersey Supreme Court - after empowering a special master to conduct extensive hearings on the weaknesses of eyewitness identification evidence -- had just mandated a new pretrial inquiry and jury instruction regime that some believe should be a model for the nation. ${ }^{97}$ State protocols are not selfenforcing, and progress may be slow, but Perry may end up being just a refusal to lead, not a rejection of a growing regulatory wave.

The Court's constitutional approach to DNA collection from arrested suspects provides another example to its reliance on, and perhaps even collaboration with, other regulatory authorities - here both from state governments and the federal political branches. It also show the extent to which the Court has been content to take a back seat to lower courts on a core crime and security issue.

Soon after DNA testing gained recognition as a powerful forensic tool for investigating and prosecuting crimes (of the sort that involve biological trace material), federal authorities established a nationwide scheme for DNA collection, storage, and analysis. At its heart was the DNA Identification Act of 1994's creation of the FBI's Combined DNA Index System (CODIS), a central repository into which federal agencies and all states can "upload" DNA profiles and in which they can search among the profiles deposited by other jurisdictions. This national database includes "offender profiles" (obtained from known persons) and samples of unknown origin gathered from crimes scenes. ${ }^{98}$ Because sample collection and profile loading efforts initially focused on convicted offenders -- who have vastly reduced Fourth Amendment protection against searches and seizures - lower courts found them to pass constitutional muster and the Supreme Court never took a case. ${ }^{99}$

In 2013, the Court found reason to intervene, when Maryland asked it to overturn a state court decision striking down the state's expansion of its collection program to those arrested for a crime of violence or burglary. The Court's opinion (by Justice Kennedy) in Maryland v. King ${ }^{100}$-- which held that "DNA identification of arrestees is a

95132 S. Ct. at $728-29$

${ }^{96}$ Dana Walsh, Note, The Dangers of Eyewitness Identification: A Call for Greater State Involvement to Ensure Fundamental Fairness, 54 B.C. L. Rev., 1415, 1434-36 (2013) (noting state court approaches).

${ }^{97}$ See State v. Henderson, 27 A.3d 872 (N.J. 2011); see also State v. Ferguson, 804 N.W.2d 586, 609 (Minn. 2011) (Anderson, J., concurring) (suggesting that, on remand, lower Minnesota court should look to Henderson for guidance).

${ }^{98}$ Erin Murphy, Relative Doubt: Familial Searches of DNA Databases, 109 Mich. L. Rev. 291, 296 (2010).

${ }^{99}$ See Anna C. Henning, Compulsory DNA Collection: A Fourth Amendment Analysis 9-11(Congressional Research Service, 2010).

100133 S. Ct. 1958 (2013). 
reasonable search that can be considered part of a routine booking procedure"101 -- has two notable features. The first is actually the lack of a feature, as Kennedy's easy balancing of the state interest in "identifying" an arrested suspect against the suspect's privacy interest stands in stark contrast with Justice Scalia's insistence (joined by Justices Ginsburg, Sotomayor and Kagan), on warrants as the touchstone for Fourth Amendment analysis. (Consider this an unsuccessful attempt at the sort of formalist intervention that has prevailed in cases like Crawford and Blakely). ${ }^{102}$

The second feature is the Court's easy confidence that the information thus obtained from suspects would not be misused. Some of this confidence may an artifice of doctrinal limitations, for Fourth Amendment doctrine has always been willfully blind to use regulation. If police can properly see and take something, Fourth Amendment has been read to say virtually nothing about how the state uses it down the road. As Erin Murphy has noted: "Even the dissent largely ignore[d] the data retention aspect of the case in favor of focusing on collection." "103 Yet Justice Kennedy did take pains to explain:

It is undisputed that law enforcement officers analyze DNA for the sole purpose of generating a unique identifying number against which future samples may be matched. ... If in the future police analyze samples to determine, for instance, an arrestee's predisposition for a particular disease or other hereditary factors not relevant to identity, that case would present additional privacy concerns not present here. ${ }^{104}$

While I make no claim about the adequacy of state regulation and the CODIS architecture to protect civil liberties as a normative matter, they certainly made a big difference to the Court in King. And the case stands as nice example of the collaborative constitutionalism that regularly (although not reliably) makes an appearance in the Court's recent work.

To see the Court deciding, in real time, which sort of constitutional approach to take on a critical set of crime and security issues, one has only to watch the Court working through recent digital surveillance cases. ${ }^{105}$ The issue in United States v. Jones $(2012)^{106}$ was whether the warrantless installation and month-long monitoring of a GPS device attached to the defendant's car violated his Fourth Amendment rights. The Court's constitutional formula for search cases - which looks to whether someone has a "reasonable expectation of privacy" in the area being searched ${ }^{107}$-- made this a tough case. After all, one who drives on public streets has no reasonable expectation of privacy

\footnotetext{
101 Id. at 1980.

${ }^{102}$ See Erin Murphy, License, Registration, Cheek Swab: DNA Testing and the Divided Court, 127 Harv.

L. Rev. 1, 27 (2013) (discussing King line-up).

${ }^{103}$ Id. at 36.

104133 S. Ct. at 1979.

${ }^{105}$ See Orin S. Kerr, An Equilibrium-Adjustment Theory of the Fourth Amendment, 125 Harv. L. Rev. 476 , 539-42 (2011).

106132 S Ct. 945 (2012).

${ }^{107}$ This reasonable expectation of privacy test was formulated by Justice Harlan in his Katz concurrence. Katz v. United States, 389 U.S. 347, 361 (1967) (Harlan, J., concurring).
} 
in where his car goes. ${ }^{108}$ But perhaps the constitution has something to say about the government's ability to essentially create an encyclopedic dossier on someone's life. And lurking underneath the question presented was the technological reality that most of us carry GPSs in our pockets in the form of cell phones.

To resolve the question presented, Justice Scalia (writing for the majority) relied on the same sort of formalist originalism that did heroic (and ultimately inadequate) work in other cases. Forget about "expectations of privacy," Scalia explained; the analytical focus should be on the actual attachment of the GPS device. Here

[t]he Government physically occupied private property for the purpose of obtaining information. We have no doubt that such a physical intrusion would have been considered a "search" within the meaning of the Fourth Amendment when it was adopted. ${ }^{109}$

A nice clear rule that Scalia admitted had nothing to say about situations where monitoring could be done "without an accompanying trespass." But it did avoid hard questions about privacy on the open road.

Joined by three others, Justice Alito scorned the disconnect between Scalia's analytical framework and the regulatory challenge (a disconnect regular feature of Scalia's criminal procedure work). "The Court's reasoning," Alito noted, largely disregards what is really important (the use of a GPS for the purpose of long-term tracking) and instead attaches great significance to something that most would view as relatively minor (attaching to the bottom of a car a small, light object that does not interfere in any way with the car's operation)." In the wake of new devices - including cell phones --- that permit precise tracking, the "best solution to privacy concerns" would likely be legislative. But since "Congress and most States have not enacted statutes regulating the use of GPS tracking technology for law enforcement purposes," "[t]he best that we can do in this case is to apply existing Fourth Amendment doctrine and to ask whether the use of GPS tracking in a particular case involved a degree of intrusion that a reasonable person would not have anticipated." And under the circumstances here - four weeks of monitoring in context of an investigation that did not involve "extraordinary offense," the line had been crossed and the Fourth Amendment violated. ${ }^{110}$

In a separate concurrence, Justice Sotomayor, while agreeing with Justice Alito that "at the very least, "longer term GPS monitoring in investigations of most offenses impinges on expectations of privacy," mused on scenarios the Court will eventually have to face, particularly with respect to tracking information "voluntarily" provided by cell phone users to cellular providers. Drawing on what some have called a "mosaic theory"

\footnotetext{
${ }^{108}$ See United States v. Knotts, 460 U.S. 276, 278-79 (1983) (holding that use of tracking device while suspect was on public thoroughfares did not violate Fourth Amendment); United States v. Karo, 468 U.S. 705,718 (1984) (holding that warrantless use of tracking device in private home violated Fourth Amendment).

${ }^{109} 132$ S. Ct. at 949.

110132 S. Ct. at 961-64 (Alito, J., concurring in the judgement) (joined by Ginsburg, Breyer, \& Kagan, JJ.).
} 
(because it looks to the potential for data points to be assembled into a detailed and complete picture), Justice Sotomayor suggested that, even in the short term, "someone might have a "reasonable societal expectation of privacy in the sum of one's public movements." She "would ask whether people reasonably expect that their movements will be recorded and aggregated in a manner that enables the Government to ascertain, more or less at will, their political and religious beliefs, sexual habits, and so on." went on to call into question what has been a foundational, albeit much criticized, Fourth Amendment precept - the "third party doctrine," which presumes that the person who voluntarily conveys information to a third-party lacks a protectable privacy interest in it. $^{112}$

In the hands of different Justices in Jones, one sees all of the Court's constitutional brushes at work. Scalia's strong formalist lines make for a nice miniature that resolves the case but without engaging the larger regulatory problem. Alito provisionally deploys the Court's standard privacy framework, with the ad hoc nature of the resulting analysis reinforcing his plea for legislative intervention and offering a different variant of regulatory restraint. Sotomayor would cut loose and start constructing a larger constitutional edifice that would be far more protective of privacy interests than the present one in the face of new technologies. Not surprisingly, those concerned about the National Security Agency's collection of metadata (and at least one district judge addressing that program ${ }^{113}$ ) have drawn heavily on her opinion.

For now, however, the Court proceeds gingerly. In Riley v. California ${ }^{114}$-- even as it refused to extend standard "search incident to arrest" doctrine to permit the police so search data accessible via a suspect's cell phone without a warrant -- the Court addressed the government's concerns about the loss of evidence and noted that exigent circumstances might support a warrantless search in particular cases. At the same time, Chief Justice Roberts laid down a marker for future doctrinal development by acknowledging that the kind of data people store (or have access to through the "cloud") on their cell phones is "qualitatively different" from the sort of information found in pockets and wallets.

We can expect additional brush strokes soon. Lower courts are figuring out whether warrantless use of GPS devices to track cars is permissible when officers have reasonable suspicion or probable cause (an argument the government was deemed to have forfeited in Jones, having failed to raise it below), ${ }^{115}$ or whether the police can freely

\footnotetext{
${ }^{111}$ Id. at 955-56 (Sotomayor, J., concurring).

112 Id. at 957; see Smith v. Maryland, 442 U.S. 735 (1979) (no protectable interest in telephone number a person dials); United States v. Miller, 425 U.S. 435, 443 (1976) ("The Fourth Amendment does not prohibit the obtaining of information revealed to a third party and conveyed by him to Government authorities, even if the information is revealed on the assumption that it will be used only for a limited purpose and the confidence placed in the third party will not be betrayed."); Orin S. Kerr, The Case for a Third-Party Doctrine, 107 Mich. L. Rev. 561 (2009)

${ }^{113}$ Klayman v. Obama, 957 F. Supp.2d 1 (D.D.C. 2013).

114134 S Ct. 2473 (2014).

115 See United States v. Katzin, 732 F.3d 187 (3d Cir. 2013).
} 
draw on past cellular tower data to track someone's past movements. ${ }^{116}$ Meanwhile, a few states have moved to require warrants for cellphone location tracking, ${ }^{117}$ and Congress is contemplating action. The contours of the emerging regulatory regime are hard to predict. But it safe to say that the Court' views on constitutional doctrine will not be the only contributor (and probably not even the most important contributor) to the new norms. $^{118}$

\section{Conclusion}

Does some metatheory explain the Court's brush strokes or must we rely on some unsatisfying (albeit correct) observations about shifting alliances on a multi-member court? I'm just not sure. In the crime and domestic security area, the Court's constitutional ambitions sometimes sound limited (consider the plea bargaining cases). Other times, they sound quite sweeping but deploy grand rhetoric and ostensibly broad doctrine to very small effect. Nor can one safely generalize the extent to which the Court will self-consciously acknowledge criminal justice dynamics and institutions outside its walls - the ones that, whether acknowledged or not, will limit or shape the effects of its doctrinal pronouncements on actual cases.

Still, I do see a connection between the proscriptive clarity of the Court's constitutional work and the doctrinal domains it addresses. This is a Court ready to say a lot - in elaborate detail - about issues that can be safely cabined. Beyond those, its forays are extraordinarily restrained, episodic, even impressionistic. This is a Court content to preside over constitutional development writ small, but not large.

\footnotetext{
${ }^{116}$ See also United States v. Davis, 754 F.3d 1205 (1 $1^{\text {th }}$ Cir. 2014) (relying on Jones to find government violated Fourth Amendment by using cellular tower location data to trace defendant's prior movements).

${ }^{117} \mathrm{http} / / \mathrm{www}$. slate.com/blogs/future_tense/2013/07/10/new_maine_law_prohibits_warantless_cellphone_tr acking.html (discussing laws in Maine and Montana)

${ }^{118}$ Concurring in Riley, Justice Alito noted: "Legislatures, elected by the people, are in a better position than we are to assess and respond to the changes that have already occurred and those that almost certainly will take place in the future." 134 S. Ct. 2497-98.
} 